\title{
Retraction notice for: "Long non-coding RNA-ROR aggravates myocardial ischemia/reperfusion injury" [Braz J Med Biol Res (2018) 51(6): e6555]
}

\author{
Weiwei Zhang ${ }^{1}$, Ying $\mathrm{Li}^{2}$, and Peng Wang ${ }^{1}$ \\ ${ }^{1}$ Department of Cardiology, Dezhou People's Hospital, Dezhou, China \\ ${ }^{2}$ Interventional Center, Dezhou People's Hospital, Dezhou, China
}

Retraction for: Braz J Med Biol Res | doi: 10.1590/1414-431X20186555 | PMID: 29694511 | PMCID: PMC5937723

The authors would like to retract the article "Long non-coding RNA-ROR aggravates myocardial ischemia/reperfusion injury" that was published in volume 51, no. 6 (2018) (Epub April 23, 2018) of the Brazilian Journal of Medical and Biological Research.

After the publication of this study, the corresponding author requested its retraction due to "the identification of data fabrication". The Editors decided to retract this paper to avoid further damage to the scientific community.

The Brazilian Journal of Medical and Biological Research remains vigilant to prevent misconduct and reinforces the Journal's commitment to good scientific practices. We regret the unprofessional behavior of the authors involved. 


\title{
Long non-coding RNA-ROR aggravates myocardial ischemia/reperfusion isury
}

\author{
Weiwei Zhang ${ }^{1}$, Ying $\mathrm{Li}^{2}$ anc Jeng Wany \\ ${ }^{1}$ Department of Cardiology, Dezhou People's upital, De. China \\ ${ }^{2}$ Interventional Center, Dezhou People'? tospital ezhou, China
}

\begin{abstract}
Long non-coding RNAs (IncRNAs) play an important role in the pathogenesis of cardic asc diseases, especially in myocardial infarction and ischemia/reperfusion (I/R). However, the underlying molecular hanism, aains unclear. In this study, we determined the role and the possible underlying molecular mechanism of IncR a- $R \quad R$ in myocardial $I / R$ injury. H9c2 cells and human cardiomyocytes (HCM) were subjected to either hypoxia/reoxygena' ( The expression levels of IncRNA-ROR were detected in serum of myocardial I/R i i , patients, H9c2 cells, and HCM by qRTPCR. Then, levels of lactate dehydrogenase (LDH), malondialdehyde ( $M$ supero dismutase (SOD), and glutathione peroxidase (GSH-PX) were measured by kits. Cell viability, apoptosis, ap tos. nclated factors, and p38/MAPK pathway were examined by MTT, flow cytometry, and western blot assays. Furthe reactive oxygen species (ROS) production was determined by H2DCF-DA and MitoSOX Red probes with flow cytome . NADPH oxidase activity and NOX2 protein levels were measured by lucigenin chemiluminescence and westarn blot. Res is showed that IncRNA-ROR expression was increased in I/R patients and in H/R treatment of $\mathrm{H} 9 \mathrm{c} 2$ cells a ri Moreover, IncRNA-ROR significantly promoted H/Rinduced myocardial injury via stimulating release of LDH, ME SOD, a viability, increased apoptosis, and regulated expression apo is-a ociated factors. Additionally, IncRNA-ROR increased phosphorylation of p38 and ERK1/2 expression and in sition of $p$ NAPK, and rescued IncRNA-ROR-induced cell injury in H9c2 cells and HCM. ROS production, NADPH oxi e avity and NOX2 protein levels were promoted by IncRNA-ROR. These data suggested that IncRNA-ROR acted a $a$ th eut agent for the treatment of myocardial I/R injury.
\end{abstract}

Key words: IncRNA; Ischemia/reperfusion (I/F , oxia/reoxygenation (H/R); Cell viability; Apoptosis

\section{Introduction}

Myocardial ischemia/reperfusion ( 2$)$ injv leads to adverse cardiovascular outcrmes follo. myocardial ischemia, cardiac surgery or $c$ arrest and is one of the major causes of morbidit, $7 r$ mortality in humans with coronary heart diser Th athology of the disease suggests that myoc? al arctic and angina pectoris are accompanied by or , o.... Jene expression (2). The underlying mole ar me anisms of myocardial l/R injury are complex ? Jude ox ative stress, intracellular $\mathrm{Ca}^{2+}$ overload, raold res tion of physiological $\mathrm{pH}$ upon reperfusion, mit nondrial per, eability transition pore, and exaggerated in $\mathrm{mm}$.on (3). Rapid alterations in ion flux and renorma on $\mathrm{C} \mathrm{H}$ following reperfusion causes severe c ity injury, characterized by cell death and incti ial deterioration because of restoration of blood (4). In injury causes local myocardial inflammation anc optosis, which in turn leads to irreversible damage to the myocardium. However, early restoration of blood flow through the occluded coronary artery might reduce mortality by limiting the infarct size and preserving cardiac function $(5,6)$. Despite restoration of blood flow, reperfusion alone seems not to be enough to save the myocardium because of the complications that arise from the loss of viability (7).

Following myocardial I/R injury, there is a sudden increase in cytokines and chemokines and influx of leukocytes into the endangered myocardial region (8). Cell survival and extracellular matrix integrity by activation of pro-apoptotic signaling pathways (including mitogen-activated protein kinases and p38) are hampered by inflammatory responses after myocardial I/R injury (9). Studies indicate that cell death is a key factor in the pathogenesis of various cardiac diseases such as heart failure, myocardial infarction, and I/R injury (1). During heart disease, myocytes are lost due to both apoptosis and necrosis (10). It suggests that necrosis plays a critical role in the pathogenesis of the cardiac disease (11). However, the underlying mechanism of cardiomyocyte death is still not clear. Thus, I/R injury is still a major problem in the treatment of myocardial ischemia. 
Long non-coding RNAs (IncRNAs) belong to a newly discovered class of genes in the human genome that have been proposed to be key regulators of biological processes (12). IncRNAs consist of more than 200 nucleotides (13). Recent evidence shows that IncRNAs play an important role in the physiological processes such as differentiation, proliferation, apoptosis, and inflammation (14). It is also observed that IncRNAs are highly regulated and specific (15). However, the role of IncRNA-ROR in myocardial I/R injury remains unclear.

The objective of this study was to investigate the role and the possible underlying molecular mechanism of IncRNAROR in myocardial I/R injury. This study will provide a new insight for the treatment of cardiomyocytes injury.

\section{Material and Methods}

\section{Serum samples}

Serum samples of 20 normal individuals and 20 patients with myocardial I/R injury were obtained from Dezhou People's Hospital. The study was approved by the Research Ethics Committee of Dezhou People's Hospital, and written informed consent was obtained from all participants. The samples were collected and frozen in liquid nitrogen, and stored at $-80^{\circ} \mathrm{C}$.

\section{Cell culture and H/R exposure}

Embryonic rat myocardium-derived cells human cardiomyocytes (HCM) were purchas American Type Culture Collection (ATCC, tured in Dulbecco's Modified Eagle's Medium MEM; Sigma, USA) containing $10 \%$ fetal a. serum (MS; Invitrogen, USA) (16). In brief, H9c cells a HCM in serum-free DMEM were placed in a midifie chamber equilibrated with $5 \% \mathrm{CO}_{2}$ and $05 \% \mathrm{~N}_{2}$ to ollowed by reoxygenation with $5 \% \mathrm{CO}_{2}$ a with $10 \%$ FCS. Hypoxia/reoxy on $(H / R)$ treatment of $\mathrm{H} 9 \mathrm{c} 2$ cells and $\mathrm{HC}^{\prime}$ ere formed as described previously. Gene exp ssio and c optotic changes were measured at $24 \mathrm{~h}$ or enation. Cells cultured under normoxic nditic were used as control.

\section{Cell transfecion}

Smal' iterfering NAs (siRNAs) targeting mRNA (si-IncF A-P R) and pcDNA3.1-IncRNA-ROR (IncRNAROR) w ynth ized by RiboBio (China). Transfections w erfo n 6-, 24-, or 96-well plates after seeded Als y re cultured for $24 \mathrm{~h}$. All transfections were done with . . insfection reagent (QIAGEN, Germany) according the manufacturer's protocol. Briefly, $5 \times 10^{3} \mathrm{cells} / \mathrm{cm}^{2}$ were seded on $200 \mu \mathrm{L} / \mathrm{cm}^{2}$ culture. The siRNAs or pcDNAs were pre-incubated with $\mathrm{HiPerFect}$ transfection reagent at room temperature for $10 \mathrm{~min}$. The complex was then transfected into the cardiomyocytes cells at a final concentration of $50 \mathrm{nM}$. The transfected cells were incubated under normal growth conditions for $48 \mathrm{~h}$.

\section{Detection of LDH, MDA, SOD, and GSH-PX}

Lactate dehydrogenase (LDH), malondialdehyd MDA), superoxide dismutase (SOD), and glutathione roxi ase (GSH-PX) commercial kits were purchased fi ngor Biotech (China). The release levels of $\mathrm{LDH}, \mathrm{ML}$. SC, and GSH-PX were measured accordin to the man acturer's instructions.

\section{Quantitative real-time PCR (qF -PCR)}

Total RNA was isolated using I'zol rea nt (Invitrogen), and complementary DNA (VA, nthesized with PrimeScript reverse trap ripl. (TaKaRa, China) and oligo-dT (20 bp) followi the marn cturer's instructions. Reverse transcription. PC, RT-PCR) or real-time PCR was performed to vze $\mathrm{mR}_{\mathrm{i}}$ expression. The RT-PCR program was fol ws: $94^{\circ} \mathrm{C}$ for $5 \mathrm{~min}$, followed by 35 cycles of $s, 50^{\circ} \mathrm{C}$ annealing for $30 \mathrm{~s}$, and $72^{\circ} \mathrm{C}$ for $30 \mathrm{~s}$. Re. ime PCR was performed using SYBR Premix $\quad$ TM II (TaKaRa) as follows: $94^{\circ} \mathrm{C}$ for $10 \mathrm{~s}$, followed 40 s of $94^{\circ} \mathrm{C}$ for $5 \mathrm{~s}, 52^{\circ} \mathrm{C}$ for $30 \mathrm{~s}$ to anneal, an $\angle$ for $15 \mathrm{~s}$. The relative level of IncRNAROR was d rrmined using the $2^{-\Delta \Delta \mathrm{Ct}}$ analysis method.

\section{Wes. $n$ blot analysis}

$\mathrm{Pr}$ eins were extracted from the primary cardiomyoIn RIPA buffer (1\% Triton X-100, $150 \mathrm{mmol} / \mathrm{L} \mathrm{NaCl}$, $5 \mathrm{rmmol} / \mathrm{L}$ EDTA, and $10 \mathrm{mmol} / \mathrm{L}$ Tris- $\mathrm{HCl}, \mathrm{pH}$ 7.0; Solarbio, nina) supplemented with a protease inhibitor cocktail (Cat: 13786-1ML, Sigma). The cell lysates were separated by $10 \%$ sodium dodecyl sulfate-polyacrylamide gel electrophoresis (SDS-PAGE) and transferred electrophoretically to a PVDF membrane (Millipore Corporation, USA). After blocking with $8 \%$ milk in PBS, $\mathrm{pH} 7.5$, the membranes were incubated with the following specific primary antibodies of Bax (ab32503), Bcl-2 (ab59348), cytochrome C (ab13575), Smac/Diablo (ab32023), cleaved-capase-3 (ab13847), cleaved-capase-9 (ab2324), p-p38 (ab47363), p38 (ab31828), p-ERK (ab214362), and ERK1/2 (ab196883; all at a dilution of 1:1000, Abcam, UK). After overnight incubation, the appropriate HRP-conjugated anti-rabbit IgG secondary antibody (ab205781, Abcam, all at a dilution of 1:5000) was subsequently applied and immunodetection was achieved using the ECL Plus detection system (Millipore Corporation) according to the manufacturer's instructions. Band intensity was quantified using Image Lab $^{\text {TM }}$ Software (Bio-Rad, China). GAPDH (ab8245, Abcam) was used as an internal control.

\section{Cell viability assay}

To explore the effect of IncRNA on cell viability, 5000 cells per well in a $100 \mu \mathrm{L}$ medium were seeded in 96-well plates. Every $24 \mathrm{~h}$ after transfection, $20 \mu \mathrm{L}$ of the 3-(4,5-dimethylthiazol-2-yl)-2,5-diphenyltetrazolium bromide (MTT) reagent (Solarbio) was added to wells and incubated with these cells for $4 \mathrm{~h}$. After removing the medium, blue formazan was dissolved with $200 \mu \mathrm{L}$ dimethyl sulfoxide (DMSO; Sigma), 
and absorbance was measured at $570 \mathrm{~nm}$. Wells containing only cardiomyocyte cells served as blanks.

\section{Cell apoptosis assay}

To quantify apoptotic cells, flow cytometry was performed with an Annexin V-fluorescein-5-isothiocyanate apoptosis detection kit (Bio-vision, USA). After transfection for $48 \mathrm{~h}$, cells were harvested in a 5-mL tube. Then, the cells were washed with cold PBS and re-suspended in $1 \times$ binding buffer (10 mM HEPES, $140 \mathrm{mM} \mathrm{NaCl}, 2.5 \mathrm{mM}$ $\mathrm{CaCl}_{2}, \mathrm{pH} 7.4$ ) at a final concentration of $1 \times 10^{6}$ cells $/ \mathrm{mL}$. FITC-AnnexinV $(5 \mu \mathrm{L})$ and propidium iodide (PI, $5 \mu \mathrm{L})$ were gently mixed and incubated with the cells for $15 \mathrm{~min}$ at room temperature. After incubation, the samples were analyzed by flow cytometry within $1 \mathrm{~h}$.

\section{Measurement of reactive oxygen species (ROS) production}

For examining the accumulation of intracellular ROS in $\mathrm{H} 9 \mathrm{c} 2$ cells, the ROS assay kit purchased from Beyotime Institute of Biotechnology (Haimen, China) was used according to the manufacturer's instructions. Briefly, after treatment, cells were grown in a 96-well plate and incubated with $10 \mu \mathrm{mol} / \mathrm{L}$ of $\mathrm{H} 2 \mathrm{DCF}-\mathrm{DA}$ at $37^{\circ} \mathrm{C}$ for $1 \mathrm{~h}$. The fluores cence intensity was measured using the fluorescence plate reader (BD Falcon, USA) at Ex./Em. $=488 / 525 \mathrm{~m}$.

\section{Measurement of mitochondrial ROS by Mito 90}

For detection of mitochondrial superoxide enerat MitoSOXRed assay (Invitrogen/Molecular U USA) was performed. In brief, the treated $\mathrm{H} 9 \mathrm{c} 2$ cells we incubated with $5 \mu \mathrm{M}$ of MitoSOX Red fo $\mathrm{min}$ at $J{ }^{\circ} \mathrm{C}$. MitoSOX Red fluorescent intensity vas de mined at $510 \mathrm{~nm}$ excitation and $580 \mathrm{~nm}$ emiss After cubation, these cells were washed twine with irypsinized, resuspended, and immediatel, an. and to flow cytometry analysis.

\section{Measurement of NA sidas activity \\ NADPH oxidase detected by using the lucigenin-enhan d cht Muminescence method as pre- viously descri 17). Bric $y$, treated cells were washed}

in PBS and re-suspended in cold Krebs-HEPES buffer. Then, $300 \mu \mathrm{L}$ cell suspensions were homogeni- $d$ with 100 strokes in a Dounce homogenizer on ice, a alir ots of the homogenates were used immediately. $\mathrm{S}$, ently $100 \mu \mathrm{L}$ of homogenates were added to $900 \mu \mathrm{L}$ nh phate buffer, $\mathrm{pH} 7.0$, containing $1 \mathrm{mM}$ EGTA, $15 \mathrm{MM}$ sucrose, $5 \mu \mathrm{M}$ lucigenin, and $100 \mu \mathrm{M} N$, $\mathrm{PH}$ to $c$ rt the reaction. Chemiluminescence was asur ry $15 \mathrm{~s}$ for $10 \mathrm{~min}$ in a luminometer. A b er blank (le.s than $5 \%$ of the cell signal) was subtracte (rom ea reading. The differences between the val on hod efore and after adding NADPH were ce' dlat and these data represented the activity of $\mathrm{P}$ ' $\mathrm{PH}$ oxic

\section{Statistical analyc}

Data are rer ied s means \pm SE. Differences between groups were $m^{r}$ a one-way ANOVA using Graphpad prism tware 6.0 (GraphPad Software, San USA). $P \quad 5$ was nsidered to be statistically significant diffe $\mathrm{nC}$

\section{Results}

Inck I-ROR was highly expressed in myocardial I/R and $\mathrm{B}$ ?

$r$ ra indicated that the expression level of IncRNARO $r$ was significantly increased by almost 2 times in the I/R ,oup compared to the normal group $(P<0.01$, Figure $1 A)$. In addition, IncRNA-ROR expression was increased by approximately 3 times in $\mathrm{H} 9 \mathrm{c} 2$ cells and $\mathrm{HCM}$ after treatment of $H / R$ compared to cells under normoxia $(P<0.05$, Figure $1 B$ and $C$ ). These data suggested that IncRNA-ROR was highly expressed in myocardial I/R and H/R.

\section{IncRNA-ROR aggravated H/R-induced myocardial damage}

$\mathrm{H} 9 \mathrm{c} 2$ cells and $\mathrm{HCM}$ were assigned to normoxia, $\mathrm{H} / \mathrm{R}$, $\mathrm{H} / \mathrm{R}+$ IncRNA-ROR, and H/R + si-IncRNA-ROR groups. The results showed that the level of LDH significantly increased after $\mathrm{H} / \mathrm{R}$ treatment compared to control cells $(\mathrm{P}<0.01)$. Overexpression of IncRNA-ROR further increased $\mathrm{LDH}$ release by almost 31.5 and $38.2 \%$ in both $\mathrm{H} 9 \mathrm{c} 2$ cells
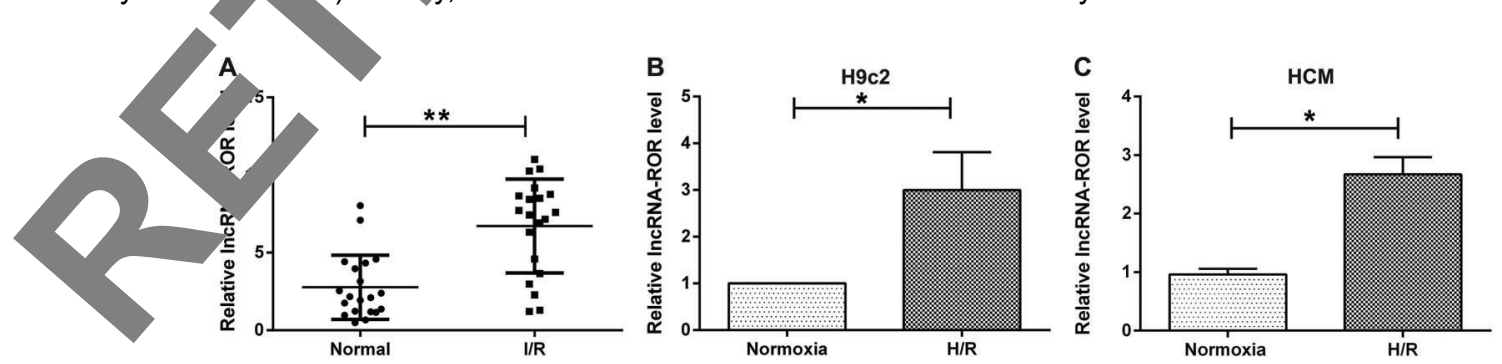

Figure 1. IncRNA-ROR was highly expressed in myocardial ischemia/reperfusion (I/R) and hypoxia/reoxygenation (H/R). A, Relative IncRNA-ROR expressions in serum of I/R injury patients and normal serum were detected by qRT-qPCR. $B$, and $C$, relative IncRNAROR expressions in H9c2 cells and human cardiomyocytes (HCM) after H/R treatment were also examined by qRT-PCR. Cells under normoxia served as the control group. Data are reported as means $\pm \mathrm{SE}$. ${ }^{*} \mathrm{P}<0.05$, ${ }^{* *} \mathrm{P}<0.01$ (ANOVA). 

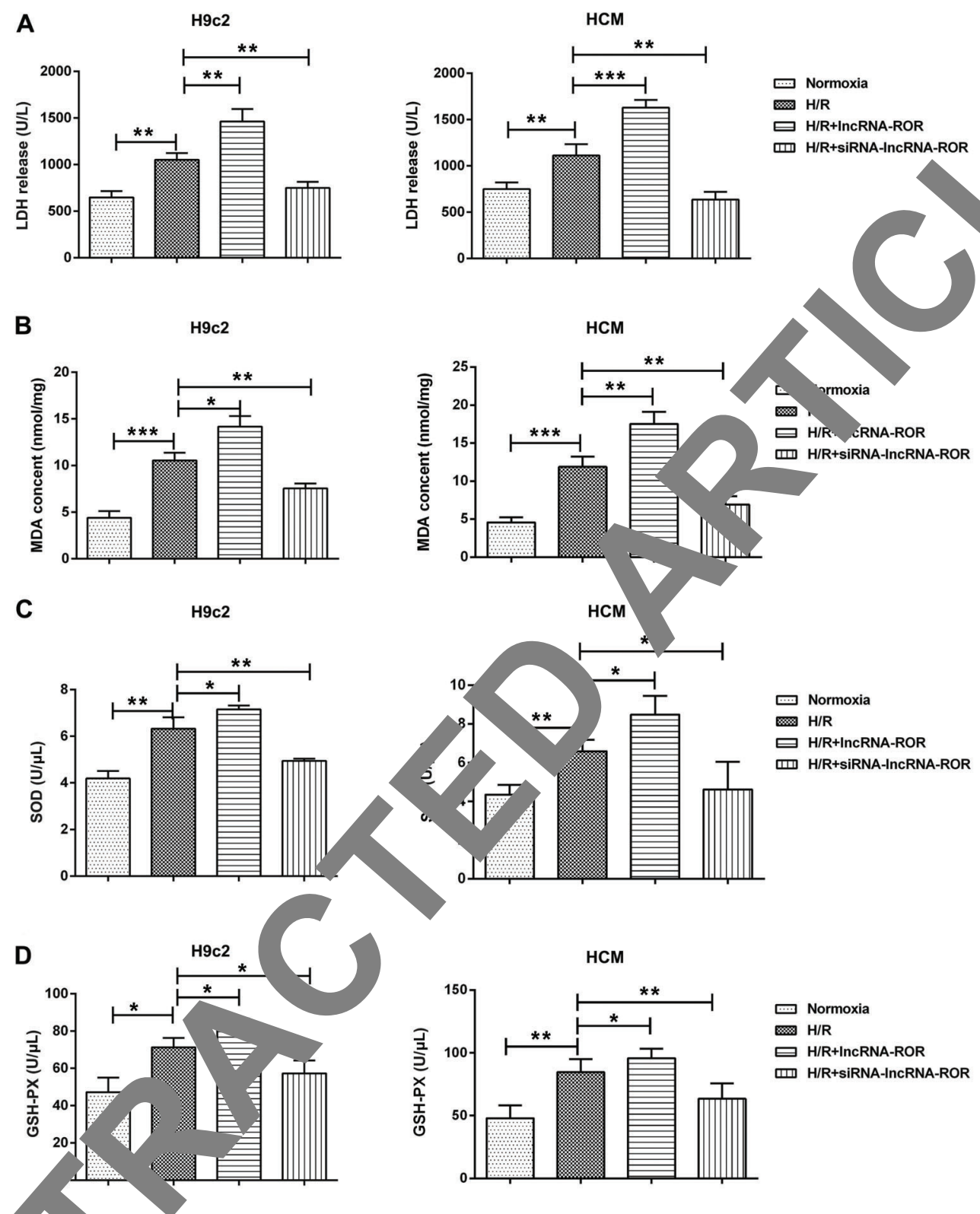

Figure 2. Cells were igned to normoxia, hypoxia/reoxygenation $(H / R), H / R+$ IncRNA-ROR, and $H / R+A S O-I n c R N A-R O R$ groups. $A$, The rele e level of ta te dehydrogenase (LDH) and levels of $(B)$ malondialdehyde (MDA), (C) superoxide dismutase (SOD), and $(D)$ glut one eroxidase (GSH-PX) in $\mathrm{H} 9 \mathrm{c} 2$ cells and human cardiomyocytes (HCM) were evaluated by kits according to the manufa or' istruc" nns. H/R + IncRNA-ROR: H9c2 cells were transfected with IncRNA-ROR after H/R treatment. H/R + si-IncRNA-ROR: H9c2 cells were . fect with si-IncRNA-ROR after H/R treatment. Data are reported as means $\pm S E$. ${ }^{*} P<0.05,{ }^{* *} P<0.01,{ }^{* \star *} P<0.001$ (ANOVA).

Civi, espectively $(P<0.01$ or $P<0.001)$, whereas, the omotive effect was obviously reversed by IncRNAROR mibition $(P<0.01)$ compared to $H / R$ in $H 9 c 2$ cells and $\mathrm{HCM}$ (Figure $2 \mathrm{~A})$.

MDA is an important index of lipid peroxidation. As shown in Figure 2B, levels of MDA in $\mathrm{H} 9 \mathrm{c} 2$ cells and $\mathrm{HCM}$ were significantly promoted after $\mathrm{H} / \mathrm{R}$ treatment compared to control cells $(P<0.001)$. As seen for $L D H$, IncRNA-ROR overexpression also increased MDA levels by 34.4 and $47.5 \%$ in $\mathrm{H} 9 \mathrm{c} 2$ cells and $\mathrm{HCM}(\mathrm{P}<0.05$ or $\mathrm{P}<0.01)$, but suppression of IncRNA-ROR decreased MDA levels by 28.4 and $42.0 \%$ respectively, compared to the H/R group.

Levels of SOD and GSH-PX were significantly increased after treatment of $\mathrm{H} / \mathrm{R}$ compared to the control group in $\mathrm{H} 9 \mathrm{c} 2$ cells and HCM (Figure $2 \mathrm{C}$ and D). Moreover, IncRNAROR overexpression increased the levels of SOD and 

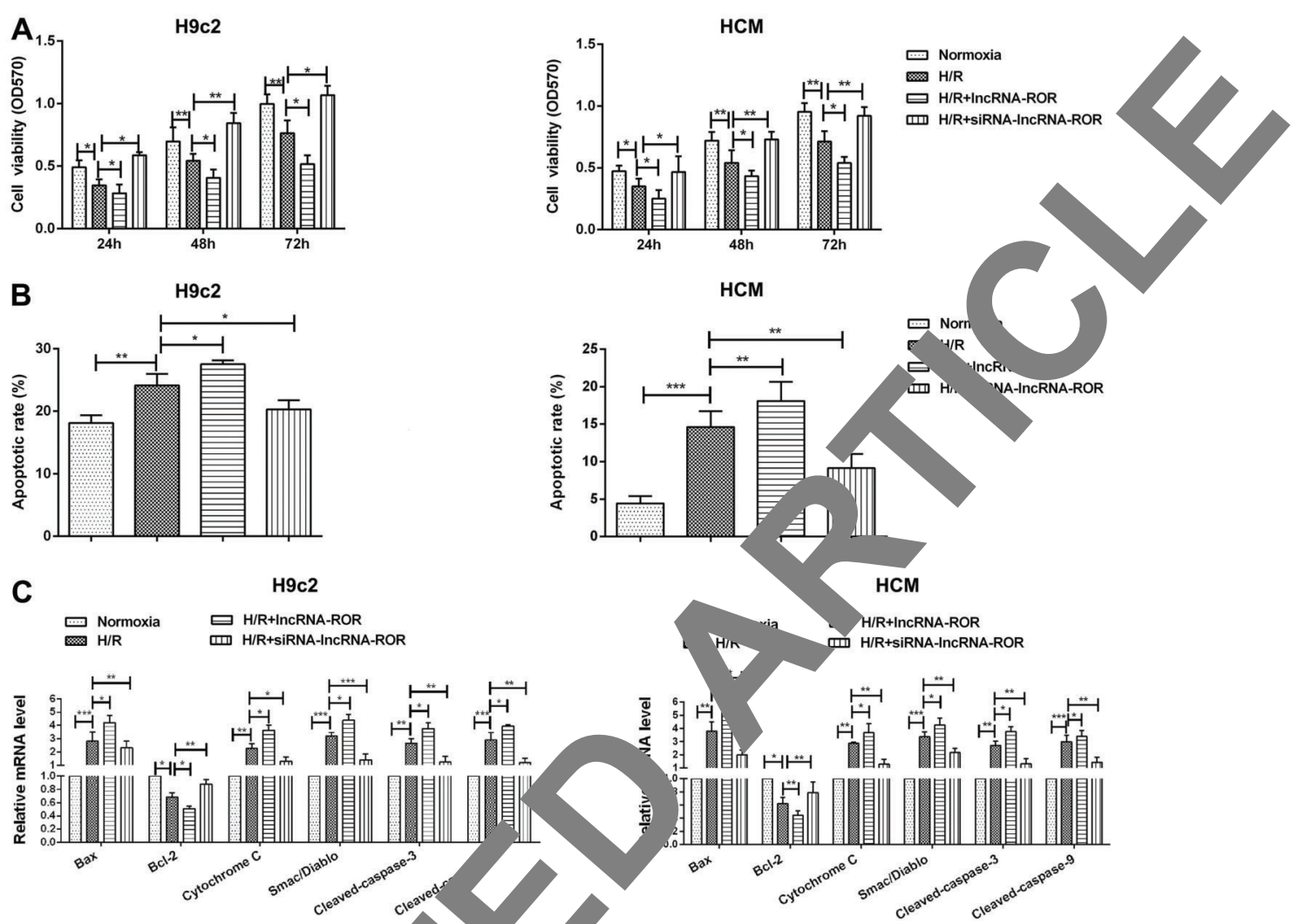

D
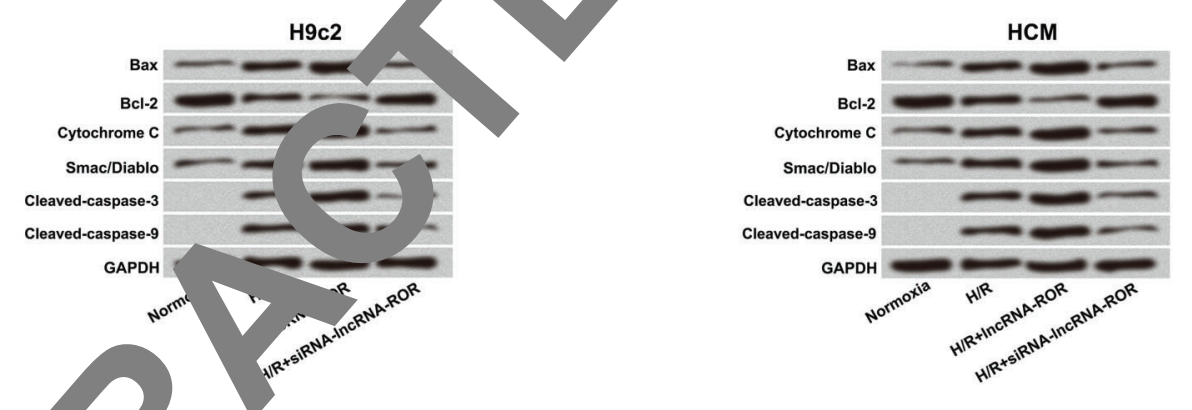

Figure 3. IncRNA-RAR and human cardic jocyte $\mathrm{HCM}$ ) were transfected with IncRNA-ROR overexpression vector (IncRNA-ROR) and inhibition vector (si-IncRNA-ROP ter H/R ti iment for $24 \mathrm{~h},(A)$ cell viability, $(B)$ apoptosis, and $(C)$ and $(D)$ apoptosis-related factors Bax, Bcl-2, cytochrome C, mac. blo, cleaved-caspase-3, and cleaved-caspase-9 were measured by MTT, flow cytometry, qRT-PCR, and western blot, respec $c^{\prime}$ ly. GAPD. Jrved as the internal control. Data are reported as means $\pm \mathrm{SE}$. ${ }^{*} \mathrm{P}<0.05,{ }^{\star \star} \mathrm{P}<0.01$, ${ }^{\star \star \star} \mathrm{P}<0.001$ (ANOVA).

GSH-P, $13.0,15.6 \%$ in $\mathrm{H} 9 \mathrm{c} 2$ cells $(\mathrm{P}<0.05)$ and 28 13. $\mathrm{HCM}$, respectively $(\mathrm{P}<0.05)$, whereas, CRN -ROR ouppression decreased by 21.9 or $19.7 \%$ in < 0.01$)$ and 30.0 or $25.0 \%$ in $\operatorname{HCM}(P<0.05)$ Co. ared to the H/R group.

\section{IncRNA-ROR aggravated H/R-induced cell injury by regulating cell viability and apoptosis}

To explore the effect of IncRNA on cell viability, the cells were transfected with IncRNA-ROR and si-IncRNAROR for 24,48 , and $72 \mathrm{~h}$. As shown in Figure $3 \mathrm{~A}$, cell viability at $24 \mathrm{~h}$ in normoxia, H/R, H/R + IncRNA-ROR, and H/R + si-IncRNA-ROR groups were $0.51,0.36(\mathrm{P}<0.05), 0.26$ $(P<0.05)$, and $0.60(P<0.05)$ in $\mathrm{H} 9 \mathrm{c} 2$ cells and $0.47,0.35$ $(P<0.05), 0.25(P<0.05)$, and $0.46(P<0.05)$ in HCM. MTT results showed that overexpression of IncRNA-ROR could further decrease the H/R-induced cell viability. We next observed the effect of IncRNA-ROR on cell apoptosis. The results showed that apoptotic cell rate in normoxia, $\mathrm{H} / \mathrm{R}, \mathrm{H} / \mathrm{R}+$ IncRNA-ROR, and H/R + si-IncRNA-ROR groups were $17.8 \%$, 23.4\% $(P<0.01), 28.7 \%(P<0.05)$, and $18.2 \%$ $(\mathrm{P}<0.05)$ in $\mathrm{H} 9 \mathrm{c} 2$ cells and $4.4 \%, 14.6 \%(P<0.001)$, 
18.1\% $(\mathrm{P}<0.01)$, and 9.1\% $(\mathrm{P}<0.01)$ in HCM. Flow cytometry showed that overexpression of IncRNA-ROR could further aggravate H/R-induced cell apoptosis (Figure 3B).

To further explore the potential molecular mechanism of action of IncRNA-ROR, expression of apoptosis-related proteins such as Bax, Bcl-2, cytochrome C, Smac/Diablo, cleaved-caspase-3, and cleaved-caspase- 9 were examined by qRT-PCR and western blot. Results revealed that $\mathrm{H} / \mathrm{R}$ markedly increased Bax, cytochrome C, Smac/Diablo, cleaved-caspase-3, and cleaved-caspase-9 expressions, but decreased Bcl-2 expression. Overexpression of IncRNAROR further increased the expression of these five factors $(\mathrm{P}<0.05)$ and decreased the level of expression of $\mathrm{Bcl}-2$ $(P<0.01$; Figure $3 C$ and $D)$. However, suppression of IncRNA-ROR showed a contrary result. These data indicated that IncRNA-ROR aggravated H/R-induced cell injury by decreasing cell viability and increasing apoptosis.

\section{IncRNA-ROR mediated myocardial H/R by regulating p38/MAPK pathway}

As shown in Figure 4A and B, phosphorylation of ERK and p38 were significantly up-regulated after treatment of $\mathrm{H} / \mathrm{R}$ in both $\mathrm{H} 9 \mathrm{c} 2$ cells and HCM. Overexpression of IncRNA-ROR further increased H/R-induced activation of phosphorylation of ERK and p38. However, inhibiti of IncRNA-ROR abolished the activated effect on $\mathrm{H9}$ cel' and HCM. These data indicated that IncRNA-R PR regulate cell growth and induce apoptosis $y^{\prime}$ activa of p38/MAPK signal pathway. The result on 'ed tha. overexpression of IncRNA-ROR synergistically ta tated $\mathrm{H} / \mathrm{R}$-induced the activation of $\mathrm{p} 38-\mathrm{MA}^{\prime}$ Nathway.
Inhibitor of p38/MAPK (SB203580) alleviated IncRNAROR-induced cell injury

To further explore the effect of p38/MAPK 1 ca diomyocytes injury, SB203580 $(10 \mu \mathrm{M})$ was us to ihibit $^{+}$ p38/MAPK expression. The results showed that $S .735$, increased IncRNA-ROR-induced cell yiability at 2.4.48, and $72 \mathrm{~h}$ after treatment of $\mathrm{H} / \mathrm{R}$ in $\mathrm{H} 9 \mathrm{c}$. ells ar $\mathrm{HCM}$ (Figure 5A). However, addition of 0350 i ificantly decreased cell apoptosis and the rate in nom roxia, H/R, $\mathrm{H} / \mathrm{R}+\mathrm{IncRNA}-\mathrm{ROR}$, and H/R + Ir RNA-RI $\mathrm{R}+\mathrm{SB} 203580$ were $17.9 \%(P<0.01), 22.5 \quad P<51.6$, and $23.1 \%$ $(P<0.01)$ in $\mathrm{H} 9 \mathrm{c} 2$ cells $n d$ d $8 \%(P<0.001), 13.2 \%$ $(P<0.01), 17.8$, and $14 \quad(P<0.4$ in $\mathrm{HCM}$ (Figure $5 \mathrm{~B})$.

Similarly, SB2035 0 re. ed apoptosis-related factors expressions. As on in $\mathrm{F}_{\mathrm{s}}$ e $5 \mathrm{C}$ and D, SB203580 down-regulated aX, tochrome C, Smac/Diablo, cleavedcaspase-3 a $a^{\prime} \quad$ aspase-9 expressions, but up-regulated $\mathrm{BCl}$ expression in $\mathrm{H} 9 \mathrm{c} 2$ cells and $\mathrm{HCM}$ $\left(\mathrm{P}<0.0^{5}\right.$ these a $\quad$ indicated that SB203580 could rescue In $\mathrm{RN} / \mathrm{C}$-induced cell viability and apoptosis in $\mathrm{H} 9 \mathrm{c} 2 \mathrm{ce}$, nd $\mathrm{HCM}$.

NA-ROK promoted ROS production in H9c2 cells

A cent study demonstrated that $\mathrm{p} 38$ and ERK were activa $d$ by oxidative stress. Therefore, we examined the of intracellular ROS production in $\mathrm{H} 9 \mathrm{c} 2$ cells. As sho.wn in Figure $6 \mathrm{~A}, \mathrm{H} / \mathrm{R}$ treatment significantly enhanced the vel of ROS formation, and the effect was further promoted by overexpression of IncRNA-ROR $(P<0.05$ or $P<0.01)$. However, suppression of IncRNA-ROR reversed the result $(P<0.01)$. To further explore the source of ROS, MitoSOX Red was used to measure mitochondria ROS production.
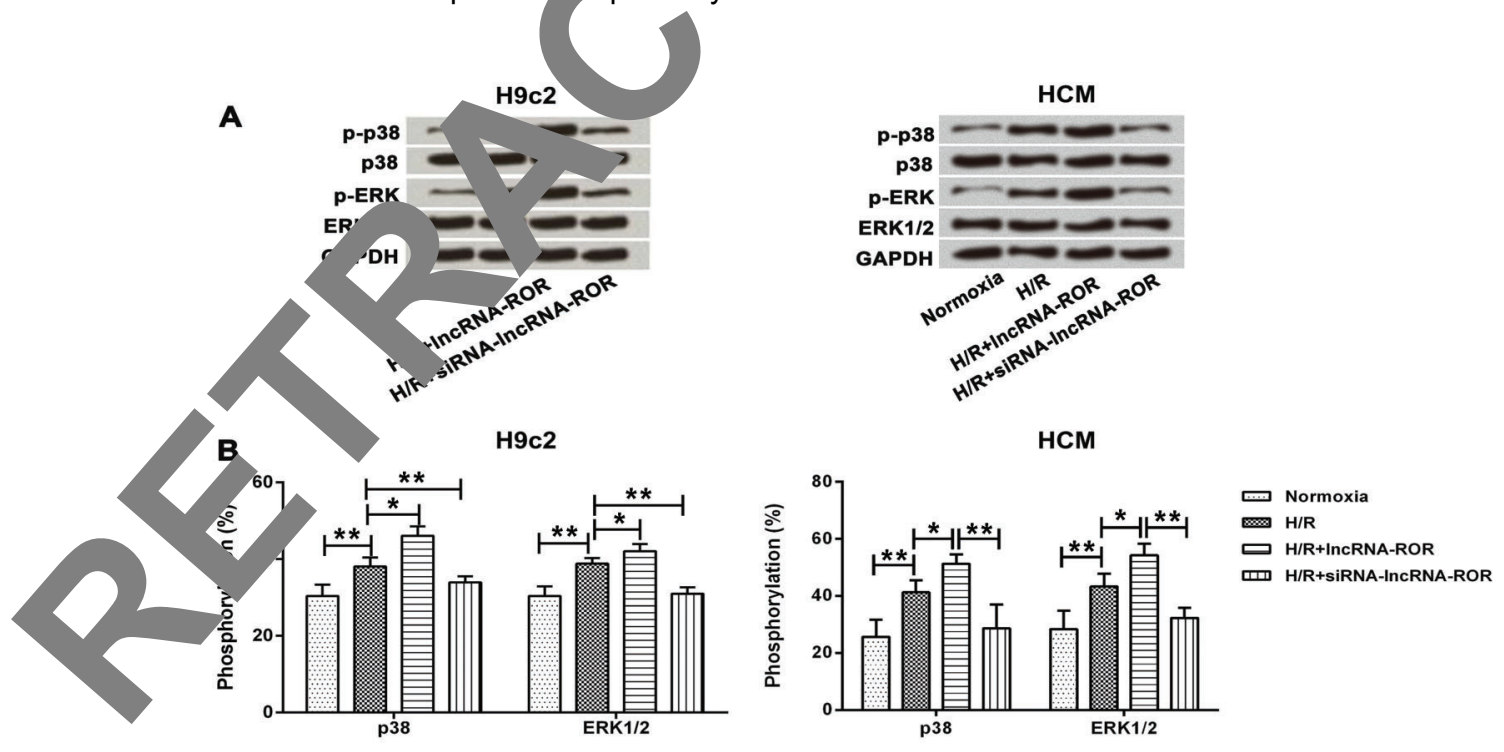

Figure 4. IncRNA-ROR mediated myocardial hypoxia/reoxygenation (H/R) by regulating the p38/MAPK pathway. H9c2 cells and human cardiomyocytes (HCM) were transfected with IncRNA-ROR overexpression vector (IncRNA-ROR) and inhibition vector (si-IncRNA-ROR). After $\mathrm{H} / \mathrm{R}$ treatment for $24 \mathrm{~h},(A)$ the protein levels of ERK and p38 were examined by western blot and $(B)$ the mRNA expressions of ERK and $\mathrm{p} 38$ were determined by $q R T-P C R$. Data are reported as means $\pm \mathrm{SE}$. ${ }^{*} \mathrm{P}<0.05,{ }^{* \star} \mathrm{P}<0.01$ (ANOVA). 

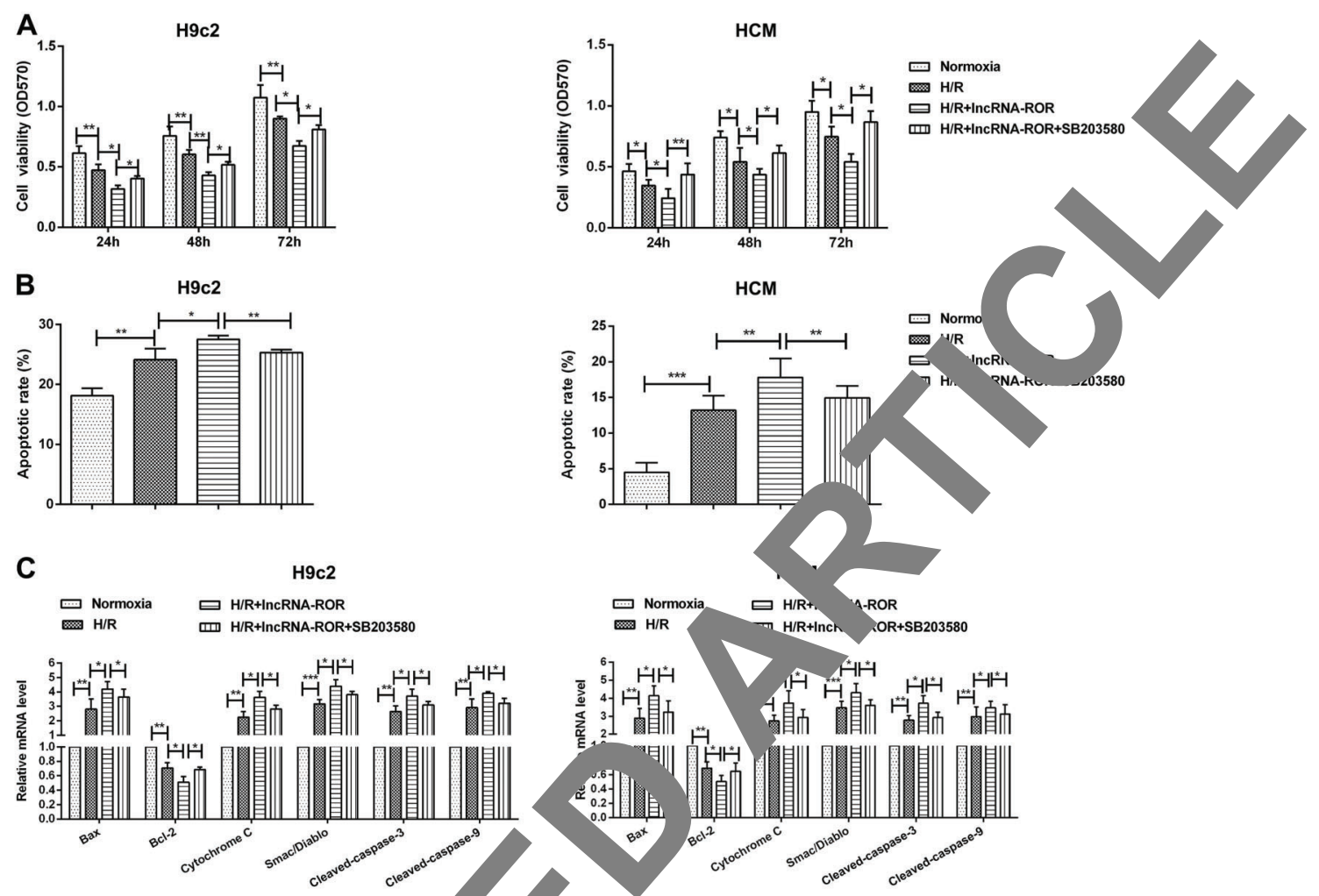

D
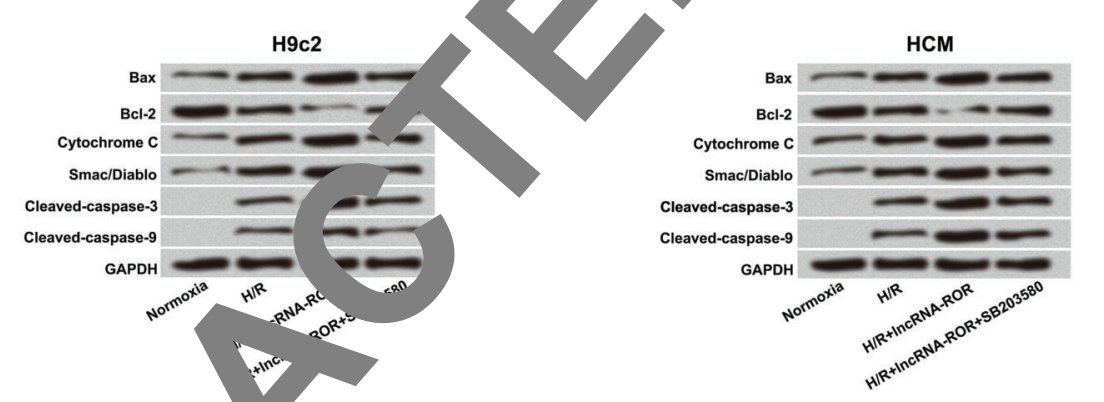

Figure 5. Inhibitor of p8/ APh SB20 30) alleviated IncRNA-ROR-induced cell injury. H9c2 cells and human cardiomyocytes (HCM) were transfected with $K$ SNA rexpression vector (IncRNA-ROR) and inhibition of p8/MAPK (SB203580, $10 \mu \mathrm{M})$ ). After hypoxia/ reoxygenation $(\mathrm{H} / \mathrm{R})$ a Smac/Diablo, clea d-caspas and cleaved-caspase-9 were measured by MTT, flow cytometry, qRT-PCR, and western blot, respectively. GAPDH served, internal untrol. Data are reported as means $\pm \mathrm{SE}$. ${ }^{*} \mathrm{P}<0.05,{ }^{* \star} \mathrm{P}<0.01,{ }^{\star \star \star} \mathrm{P}<0.001$ (ANOVA).

In Figure $B$, the Ro in mitochondria was significantly increas $1 / R$ treatment condition $(P<0.05)$. Overexpress, Inc $^{5}$ AA-ROR further promoted mitochondria $\mathrm{R}$ rodu. $(\mathrm{P}<0.05)$. However, the promoting effect ere eclinea by IncRNA-ROR suppression $(P<0.05)$. $\checkmark$ were similar with intracellular ROS production.

DPH oxidase plays a crucial role in ROS production, a d NOX2 was an important member of the NADPH oxidase family. Therefore, NADPH oxidase activity and NOX2 protein level were examined in $\mathrm{H} 9 \mathrm{c} 2$ cells. As revealed in Figure 6C, IncRNA-ROR overexpression enhanced $H / R$-induced NADPH oxidase activity $(P<0.05)$. In contrast, IncRNA-ROR suppression decreased NADPH oxidase activity $(P<0.05)$. Western blot results displayed that the protein level of NOX2 was increased by H/R treatment, and further enhanced by IncRNA-ROR overexpression. However, IncRNA-ROR suppression reduced NOX2 protein level (Figure 6D). These data revealed that IncRNAROR could promote ROS formation in H9c2 cells.

\section{Discussion}

According to World Health Organization estimates, coronary heart disease is the leading cause of death and about 17.5 million people died from cardiovascular disease in 2012 (18). The effects of coronary heart 
A

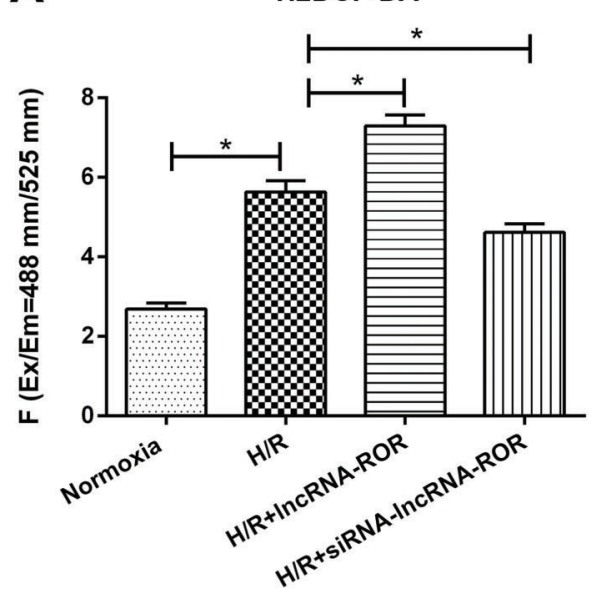

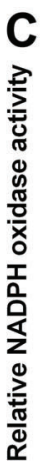

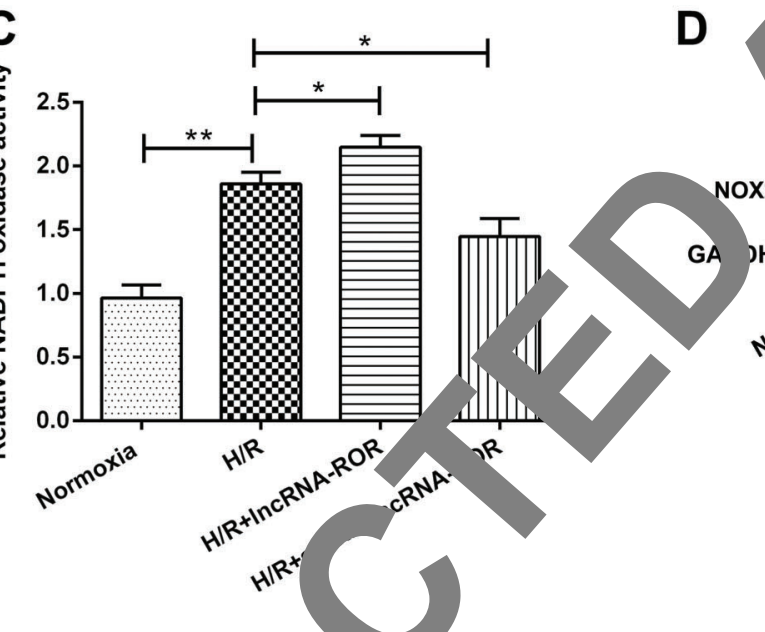

B

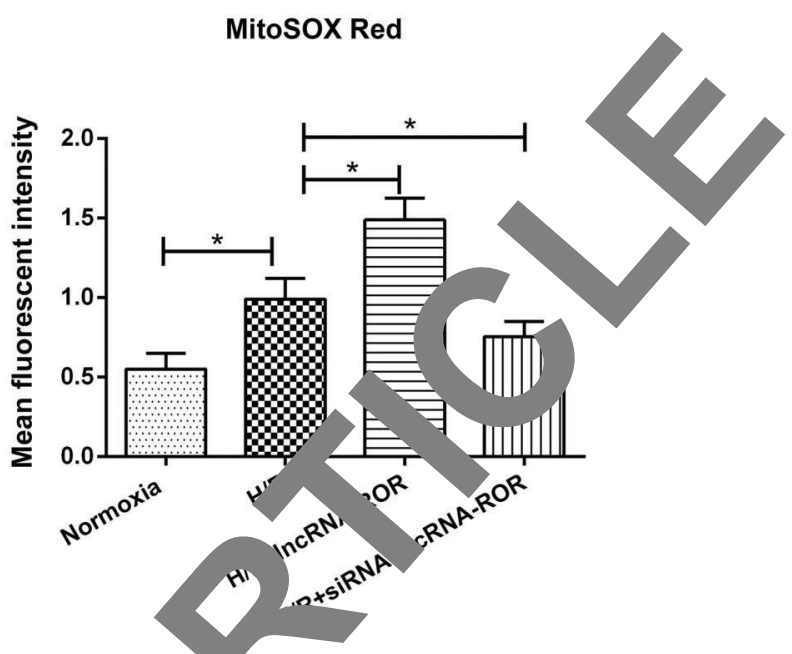

Figure 6. IncRNA-ROR promoted tive oxygen species (ROS) production in H9c2 cells. H9c2 cells were transfected with IncRNAROR overexpression vector (IncR A-n $y$ nd inhibition vector (si-IncRNA-ROR). After hypoxia/reoxygenation (H/R) treatment for $24 \mathrm{~h},(A)$ intracellular ROS product MitoSOX Red assay; $(C)$ th vity $\mathrm{ADPH}$ oxidase was measured by chemiluminescence assay; $(D)$ the protein level of NOX2 was examined by western b' Dal are re rted as means $\pm S E$. ${ }^{*} P<0.05$, ${ }^{* *} P<0.01$ (ANOVA).

disease are usu can do by the detrimental effects of acute myocar $/ R$. The ocess of myocardial I/R can induce its cell dan and death (19). Since the underlying mer anism of th. myocardial I/R injury is unclear, cardioy,culs disease remains a leading cause of hospitalization a eath robally (20). Therefore, in the present st we ed the functional role of IncRNA-ROR my cardial $/ R$ injury. Our results showed that high of IncRNA-ROR was observed in I/R patients an $\mathrm{H} / \mathrm{R}$ treatment of $\mathrm{H} 9 \mathrm{c} 2$ cells and HCM. Moreover, IncR . -ROR overexpression further increased LDH, MDA, SOD, and GSH-PX releases in $\mathrm{H} / \mathrm{R}$ treatment $\mathrm{H} 9 \mathrm{c} 2$ cells and HCM. The findings suggest that IncRNA-ROR may aggravate $\mathrm{H} / \mathrm{R}$-induced myocardial damage.

Recent studies have suggested the critical role of IncRNAs in the regulation of gene expression, which are shown to play an important role in the pathogenesis of cardiovascular diseases $(21,22)$. In another study, it was shown that IncRNA had a protective function for heart from pathological hypertrophy by interfering with the binding of a chromatin remodeling factor Brg1 to chromatinized DNA targets (23). There are several indications that IncRNAs may function as pro-apoptotic or anti-apoptotic regulators (24). Apoptosis plays a crucial role in myocardial I/R (25). In ischemically damaged tissues, activation of pro-death $\mathrm{Bcl}-2$ proteins such as Bax, Bak, Bid, Puma, and BNIP3 and their upregulation, translocation, and integration into mitochondria have been reported (26-28). However, many of these proteins are redox sensitive, which is supported by the fact that ischemia alone is not sufficient for $\mathrm{Bcl}-2$ protein activation and that reperfusion is required $(29,30)$. Both pro- and anti-apoptotic $\mathrm{Bcl}-2$ proteins regulate $\mathrm{Ca}^{2+}$ 
homeostasis, which influences I/R injury (31). Our results were in line with these findings, which showed that due to overexpression of IncRNA-ROR the level of expression of $\mathrm{Bcl}-2$ was decreased, which in turn led to a higher apoptosis rate. Furthermore, overexpression of IncRNAROR further increased the level of expression of Bax proteins. These findings indicated that IncRNA-ROR increased cardiomyocyte apoptosis.

To further illustrate the underlying molecular mechanism for apoptosis, which is mediated by IncRNA-ROR, MAPKs such as p38 and ERK were measured. Several studies have indicated that activation of $\mathrm{p} 38$ occurs during I/R $(32,33)$, whereas inhibition of $p 38$ has shown reduction in I/R-induced cell death $(34,35)$. We observed that IncRNA-ROR mediated myocardial $H / R$ by regulating the $\mathrm{p} 38 / \mathrm{MAPK}$ pathway. This was further proved by the impact of addition of p38 inhibitor (SB203580) to the $\mathrm{H} 9 \mathrm{c} 2$ cells. It was observed that SB203580 could rescue IncRNA-ROR-induced cell viability, expression of Bax and $\mathrm{Bcl}-2$, and reduce apoptotic cells rate. These findings are similar to the results obtained in other conditions such as renal $\mathrm{I} / \mathrm{R}$ injury cells (34), brain cells (35), and chronic myelogenous leukemia K562 cells (36).

Recent studies have demonstrated that ROS is closely related to diverse signal pathways including p38/MAPK (37).
Moreover, the production of ROS has been proven to be involved in regulation of myocardial I/R injury $(3)$. In a recent study, Kim et al. (39) demonstrated tr $\left(\mathrm{P}^{\mathrm{y}} \mathrm{OT}\right.$ alleviated myocardial I/R injury via decreasing ra slular levels of ROS. Furthermore, mitochondrial ano $\mathrm{AD}^{\mathrm{r}}$ i oxidase are important sources of ROS and the $\mathrm{N}, \mathrm{SH}$ oxidase family member of NOX2 exertec import th role in ROS production (40). Based or se s. 'is we further explored the effect of IncRN/ ROR on RO formation in myocardial $\mathrm{I} / \mathrm{R}$ injury. We $\mathrm{t}$ ind the IncRNA-ROR overexpression significantly cre intracellular ROS and mi cho, RUS. Moreover, the NADPH oxidase activit d NOX otein level were also promoted by IncRNA $2 \mathrm{O}$ erexpression in $\mathrm{H} 9 \mathrm{c} 2$ cells. These data indic that In NA-ROR-promoted myocardial I/R injur mic be associated with the induction of ROS gener. studies still need to clarify the hypothesis.

In ce ion, we ave shown that IncRNA-ROR plays a crucial le c cardial I/R injury by regulation of the p38/MAPK, nal pathway. Our results suggested that IncRNA-RO, might be an important therapeutic target nyocardial $\mathrm{I} / \mathrm{R}$ injury and this finding may help in the elopment of a new strategy for the treatment of myoc: dial I/R injury.

\section{References}

1. Whelan RS, Kaplinskiy V, Kitsis RN. Cell dea the path genesis of heart disease: mechanisms d $\mathrm{d}$. ificance. Ann Rev Physiol 2010; 72: 19, doi: 10.1146/annurev. 'siol. 010908.163111

2. Dabek J, Owczarek A, Gasior Z, L zok R, ? owerski M, Kułach A, et al. Oligonucleotide micrc ay anal is of genes regulating apoptosis in chronically ischer. postinfarction myocardium. Biochem Genet 241-247, doi: 10.1007/ s10528-007-9137-3.

3. Thind GS, Agrawal PR. Hirsh B, volatz L, Chen-Scarabelli $C$, Narula J, et al ne anism of myocardial ischemiareperfusion injury d the scope and limitatio. sure curdiol 2015; 11: 61-76, doi: 10.2217/fca. 1 6.

4. Turer AT. A. Patho énesis of Myocardial ischemiareperfusion inju, nd rationale for therapy. Am J Cardiol 2010 J6: 360-36 doi: 10.1016/j.amjcard.2010.03.032.

5. Ze XC XS, Wen H. Telmisartan protects against microvas aysfur ion during myocardial ischemia/reperfusion iury L on of peroxisome proliferator-activated receptor Ima. L C Cardiovasc Disord 2013; 13: 39, doi: 10.1186/ 13-139.

Arslan F, Smeets MB, O'Neill LA, Keogh B, Mcguirk P, nmers $L$, et al. Myocardial ischemia/reperfusion injury is mediated by leukocytic toll-like receptor- 2 and reduced by systemic administration of a novel anti-toll-like receptor-2 antibody. Circulation 2010; 121: 80-90, doi: 10.1161/ CIRCULATIONAHA.109.880187.

7. Cannon CP, Gibson CM, Lambrew CT, Shoultz DA, Levy D, French WJ, et al. Relationship of symptom-onset-to-balloon time and door-to-balloon time with mortality in patients undergoing angioplasty for acute myocardial infarction. JAMA 2000; 283: 2941-2947, doi: 10.1001/jama.283.22.2941.

8. Arslan F, de Kleijn DP, Timmers L, Doevendans PA, Pasterkamp G. Bridging innate immunity and myocardial ischemia/reperfusion injury: the search for therapeutic targets. Curr Pharmac Design 2008; 14: 1205-1216, doi: 10.2174/ 138161208784246090.

9. Sugden PH, Clerk A. "Stress-responsive" mitogen-activated protein kinases (c-Jun $\mathrm{N}$-terminal kinases and p38 mitogen-activated protein kinases) in the myocardium. Circ Res 1998; 83: 345-352, doi: 10.1161/01.RES.83.4.345.

10. Anversa P, Kajstura J. Myocyte cell death in the diseased heart. Circ Res 1998; 82: 1231-1233, doi: 10.1161/01.RES. 82.11.1231.

11. Mccully JD, Wakiyama $H$, Hsieh YJ, Jones M, Levitsky S. Differential contribution of necrosis and apoptosis in myocardial ischemia-reperfusion injury. Am J Physiol Heart Circ Physiol 2004; 286: H1923-H1935, doi: 10.1152/ajpheart. 00935.2003.

12. Ponting CP, Oliver PL, Reik W. Evolution and functions of long noncoding RNAs. Cell 2009; 136: 629, doi: 10.1016/ j.cell.2009.02.006.

13. Archer K, Broskova Z, Bayoumi AS, Teoh J, Davila A, Tang $\mathrm{Y}$, et al. Long non-coding RNAs as master regulators in cardiovascular diseases. Int J Mol Sci 2015; 16: 2365123667, doi: 10.3390/ijms161023651.

14. Gao W, Wang ZM, Zhu M, Lian XQ, Zhao $H$, Zhao D, et al. Altered long noncoding RNA expression profiles in the myocardium of rats with ischemic heart failure. J Cardiovasc 
Med 2015; 16: 473-479, doi: 10.2459/JCM.0b013e3283 $6499 \mathrm{~cd}$.

15. Derrien T, Johnson R, Bussotti G, Tanzer A, Djebali S, Tilgner $\mathrm{H}$, et al. The GENCODE $\mathrm{v} 7$ catalog of human long noncoding RNAs: Analysis of their gene structure, evolution, and expression. Genome Res 2012; 22: 1775, doi: 10.1101/ gr.132159.111.

16. Wu Z, Qi Y, Guo Z, Li P, Zhou D. miR-613 suppresses ischemia-reperfusion-induced cardiomyocyte apoptosis by targeting the programmed cell death 10 gene. Biosci Trends 2016; 10: 251-257, doi: 10.5582/bst.2016.01122.

17. Cariello M, Simone S, Loverre A, Gigante M, Incampo F, Pietanza $S$, et al. Coagulation activation is associated with nicotinamide adenine dinucleotide phosphate oxidasedependent reactive oxygen species generation in hemodialysis patients. Antioxid Redox Signal 2012; 16: 428-439, doi: 10.1089/ars.2011.4062.

18. Cardiovascular diseases (CVDs). Available at: http://www. who.int/mediacentre/factsheets/fs317/en/.

19. Yellon DM, Hausenloy DJ. Myocardial reperfusion injury. N Engl J Med 2007; 357: 1121-1135, doi: 10.1056/NEJM ra071667.

20. Barnett $P$, Hoff MJBVD. Cardiac regeneration: different cells same goal. Med Biol Eng Comput 2011; 49: 723-732, doi: 10.1007/s11517-011-0776-5.

21. Thum T, Condorelli G. Long noncoding RNAs and microRNAs in cardiovascular pathophysiology. Circ Res 2015, 116: 751, doi: 10.1161/CIRCRESAHA.116.303549.

22. Condorelli G, Latronico MV, Cavarretta E. micro cardiovascular diseases: current knowledge and ahead. J Am Coll Cardiol 2014; 63: 2177-2187, j.jacc.2014.01.050.

23. Liu ZG, Tang B, Zeng $Y$, He N, Wang $Z A_{L}, H$, et al. Mitochondrial genome of a spontaneous multip myeloma bone cancer model mouse $\mathrm{C}^{5}$ C.KaLwRij Suain. Mitochondrial DNA A DNA Mapp seq An 2015; 27: 4071-4072.

24. Gazzaniga FS, Blackburn EH. An a. stic role for telomerase RNA in human cells independent of telomere integrity or telome e e ic activity. Blood 2014; 124: 3675-3684, doi: 10 . olood-2014-06-582254.

25. Puyal J, Vaslin A r V, arke PG. Postischemic treatment of neon a cer oral isc emia should target autophagy. Ann Neurol a o. o 89, doi: 10.1002/ana.21714.

26. Wei $Q$, Yin $A M$, $~ M H$, Dong $Z$. Bid deficiency ameliorate nemic ren failure and delays animal death in C57BL, o mic Am J Physiol Renal Physiol 2006; 290: F35-F 2, doi: 10. \%/ajprenal.00184.2005.

27. Wu, Qi V, Wang P, Yu H, Cheng T, Zambetti GP, et al. ps " $n$ ' Jende induction of PUMA mediates intestinal nop. in sponse to ischaemia-reperfusion. Gut 2007; 645, 10.1136/gut.2006.101683.

8. N Aruri MR, Beerstolz D, Namas RA, Dhupar R, Torres A, Lougnian PA, et al. Expression and subcellular localization of BNIP3 in hypoxic hepatocytes and liver stress. Am J Physiol Gastrointest Liver Physiol 2009; 296: G 9, doi: 10.1152/ajpgi.90526.2008.

29. Diwan A, Krenz M, Syed FM, Wansapura J, RC K sters $A G$, et al. Inhibition of ischemic cardiomyocyte opto through targeted ablation of Bnip3 restrains pos ction remodeling in mice. $J$ Clin Inve $007 ; 117$; 20252833, doi: 10.1172/JCl32490.

30. Ben-Ari Z, Pappo O, Cheporko asovic Offen D, Shainberg $A$, et al. Bax ablati protectragainst hepatic ischemia/reperfusion injury in tr. genic $n$ e. Liver Transpl 2007; 13: 1181-1188, doi. $10 \mathrm{u}$ o1

31. Scorrano L, Oakes SA pfe $\eta J$ J, Cheng EH, Sorcinelli $M D$, Pozzan T, et $? A X$ ana $K$ regulation of endoplasmic reticulum C . ontrol point for apoptosis. Science 2003; 300: 135-139, doi: $1 \mathrm{c}$ 26/science.1081208.

32. Harding SJ, F vw GJ, Miller BW, Prigent SA, Dickens M. Activation o SK1 ininstream MAPKK and MAPK isoforms during cardic aerma. Biochim Biophys Acta 2010; 1802: 733-740, doi: 1 16/j.bbadis.2010.06.005.

33. Tak Nozakl, Sugino T, Hattori I, Hashimoto N. Phos, ory of c-Jun $\mathrm{NH}(2)$-terminal kinase and p38 mitoge avated protein kinase after transient forebrain ischemia mice. Neurosci Letters 2000; 294: 117, doi: 10.1016/ S0304-39، O(00)01552-4.

34. ngshan LI, Ding T, Liu X, Caixia LI. Influence of 203580 on Cell apoptosis and P38MAPK in renal nemia/reperfusion injury. J Huazhong Univ Sci Technolog Med Sci 2006; 26: 50-52, doi: 10.1007/BF02828037.

25. Piao CS, Kim JB, Han PL, Lee JK. Administration of the p38 MAPK inhibitor SB203580 affords brain protection with a wide therapeutic window against focal ischemic insult. J Neurosci Res 2003; 73: 537-544, doi: 10.1002/jnr.10671.

36. Ha SH. Jellyfish extract induces apoptotic cell death through the p38 pathway and cell cycle arrest in chronic myelogenous leukemia K562 cells. PeerJ 2017; 5: e2895, doi: 10.7717/peerj.2895.

37. Duan F, Yu Y, Guan R, Xu Z, Liang H, Hong L. Vitamin K2 induces mitochondria-related apoptosis in human bladder cancer cells via ROS and JNK/p38 MAPK signal pathways. Plos One 2016; 11: e0161886, doi: 10.1371/journal.pone.0161886.

38. Pisarenko O, Shulzhenko V, Studneva I, Pelogeykina Y, Timoshin A, Anesia R, et al. Structural apelin analogues: mitochondrial ROS inhibition and cardiometabolic protection in myocardial ischaemia reperfusion injury. $\mathrm{Br} J$ Pharmacol 2015; 172: 2933-2945, doi: 10.1111/bph.13038.

39. Kim J, Kim J, Kook H, Park WJ. PICOT alleviates myocardial ischemia-reperfusion injury by reducing intracellular levels of reactive oxygen species. Biochem Biophys Res Commun 2017; 485: 807-813, doi: 10.1016/j.bbrc.2017.02.136.

40. Lin $\mathrm{N}$, Zhang $\mathrm{H}$, Su Q. Advanced glycation end-products induce injury to pancreatic beta cells through oxidative stress. Diabetes Metab 2012; 38: 250, doi: 10.1016/j.diabet.2012. 01.003 . 